\title{
Information and Communication Technology (ICT) Key Tool for Enhancing Teaching and Learning in Nigeria: A Study of Two Tertiary Institutions in Benin Metropolis
}

\author{
Kingsley Obahiagbon ${ }^{1, *}$, Otabor Joseph Osahon ${ }^{2}$ \\ ${ }^{1}$ Department of Mathematics and Computer Science, Benson Idahosa University Benin City, Nigeria \\ ${ }^{2}$ Medical Director's Office, Federal Neuro Psychiatric Hospital, Benin City, Nigeria \\ *Corresponding author: kobahiagbon@biu.edu.ng
}

Received October 21, 2014; Revised December 20, 2014; Accepted December 24, 2014

\begin{abstract}
Survey method was adopted in this work. Usable data were collected from 200 students and lecturers of University of Benin and Benson Idahosa University through randomly administered questionnaires. Data that relates to the research questions were analyzed using frequency count and percentage, while the Null hypothesis was tested using chi square test. The results showed a strong relationship between the use of ICT tools and enhancement in teaching and learning. Recommendations for more investment in ICT based teaching and learning tools, acquisition of ICT skills and the integration of ICT education in school curriculums were proffered.
\end{abstract}

Keywords: curriculum, ICT, educational tools

Cite This Article: Kingsley Obahiagbon, and Otabor Joseph Osahon, "Information and Communication Technology (ICT) Key Tool for Enhancing Teaching and Learning in Nigeria: A Study of Two Tertiary Institutions in Benin Metropolis." American Journal of Educational Research, vol. 2, no. 12 (2014): 1257-1259. doi: 10.12691/education-2-12-20.

\section{Introduction}

The Nigeria National Information Communication Technology (ICT) Policy (Federal Republic of Nigeria, 2012) envisioned Nigeria as a knowledge-based and globally competitive society whose mission is to fully integrate information and communication technologies into the socio-economic development and transformation of Nigeria into a knowledge based economy. Effective ICT-based teaching and learning in our educational institutions would help fulfill this vision. When the meaning of ICT and its unlimited offer to education are understood, then this rapidly changing technology would not be seen as overwhelming issues, but an enabler to more critical thinking and problem solving in education. According to Bransford et al. (2000) several studies have reviewed literatures on ICTs and learning and have concluded that it has great potential to enhance student achievement and teacher's learning. In the view of Moursund (2005), information accessed through digital technologies can promote innovation, increase productivity and enrich the quality of lives, adding that application of ICT in education is broad, deep and rapidly growing field of study and has the potential to contribute to substantial improvement in the educational system. Iloanusi and Osuagwu (2009) surveyed online presence of 70 higher education institutions and found 46 Nigerian universities have an online presence whereas 24 are not online. The rapid expansion and evolution of ICTs have qualitatively changed the nature of teaching and learning in developed countries and it provides opportunity for improved teaching and learning methods in Nigerian tertiary institutions. Adeyemi \& Olaleye (2010) states information and knowledge changes rapidly hence teaching and learning processes as well as school management has to change. They opined that the use of ICT can potentially improve education quality, expand learning opportunities and make education accessible

\section{Purpose of the Study}

The purpose of this study was to investigate the awareness, accessibility, level of satisfaction and effectiveness in the utilization of ICTs in enhancing teaching and learning at the University of Benin and Benson Idahosa University, both situated in Benin City Edo state Nigeria.

\section{Research Questions}

1. What ICT facility are available and in use in enhancing teaching and learning in tertiary institutions in Benin City metropolis?

2. Are ICT facilities adequately utilized in enhancing teaching and learning in tertiary institutions in Benin City metropolis? 


\section{Materials and Methods}

\subsection{The University of Benin}

The University of Benin was founded in 1970 as the institute of Technology and was accorded the status of a full-fledged University by the National University Commission (NUC) on $1^{\text {st }}$ July, at various levels: Postgraduate, Undergraduate, Diploma and Certificate. Presently, the total students' enrolment stands at over 40,000 (staff strength ranges 4000 - 4999 (www.4icu.org/reviews/3459.htm) made up of both full time and part-time students shared among the various faculties of Agriculture, Arts, Education, Engineering, Law, Life Sciences, Pharmacy, Physical Sciences, Social Sciences and the College of Medicine. (UNIBEN, 2012)

\subsection{The Benson Idahosa University}

Benson Idahosa University was founded by the late Archbishop of Church of God Mission InternationalBenson Idahosa. The university was first accredited in 2002 by The National University Commission (NUC). The University offers Postgraduate, Undergraduate, Diploma and Certificate courses. The total students' population ranges from 4000 - 4999 with staff range 300 399. Available faculties are: Arts and Education, Basic and Applied Science, Law, Social and Management Science (www.4icu.org/reviews/3451.htm).

\subsection{Methods}

The design for the study was descriptive survey. The study sample comprised 200 respondents divided into 150 $(75 \%)$ students and 50 (25\%) lecturers from both University of Benin and Benson Idahosa University. Since the University of Benin has a higher population of students and lecturers than Benson Idahosa University, 130 questionnaires were randomly administered at the University of Benin made up of $32(25 \%)$ lecturers while 98 (75\%) students) while 70 questionnaires were administered at Benson Idahosa University made up of 18 (26\%) lecturers and $52(74 \%)$ students. All 200 of the questionnaires were received completely filled amounting to $100 \%$ useable and return rate. Distribution of respondents based on faculty was 50 (25\%) Physical Sciences; 50 (25\%) Life Sciences; 38 (19\%) Medical Sciences; 25 (12.5\%) Arts; 17 (8.5\%) Management Sciences; 13 (6.5\%) Education; 6 (3\%) Law; 1 (0.5\%) Agricultural Sciences. Data collected were tabulated and analyzed using percentage and frequency count. Chi square test of independence was used to test the null hypothesis using SPSS version 16.0

\section{Result and Discussion}

Research Question 1: What ICT facility are available and in use in enhancing teaching and learning in tertiary institutions in Benin City metropolis?

Table 1. Level of availability and use of ICT facilities in Nigerian tertiary institutions

\begin{tabular}{|c|c|c|c|c|}
\hline Facilities & Available (frequency) & Percentage & Not available (frequency) & Percentage \\
\hline Desktop/Laptop Computer system & 130 & 65 & 70 & 35 \\
\hline Internet service & 180 & 90 & 20 & 10 \\
\hline Photocopying machine & 200 & 100 & 0 & 0 \\
\hline On-line Electronic library & 10 & 5 & 190 & 95 \\
\hline Multimedia Projector & 20 & 10 & 180 & 90 \\
\hline Telephone & 200 & 100 & 0 & 0 \\
\hline Scanning machine & 135 & 67.5 & 65 & 32.5 \\
\hline Printer & 120 & 60 & 80 & 40 \\
\hline Digital/Analogue Television & 20 & 10 & 180 & 90 \\
\hline Satellite dish/Communication antenna & 190 & 95 & 10 & 5 \\
\hline Interactive Whiteboard & 0 & 0 & 200 & 100 \\
\hline Video recorder & 10 & 5 & 190 & 95 \\
\hline
\end{tabular}

Table 1 shows the frequency count and percentage of ICT facilities available for use in enhancing teaching and learning in two universities in Benin metropolis of Edo state of Nigeria. It was revealed that only photocopying machine $(100 \%)$ and telephone $(100 \%)$ are available and adequately used while other facilities are at different level of availability and use in enhancing teaching and learning in tertiary institutions in Benin metropolis of Nigeria. finding indicates that $(65 \%),(90 \%),(5 \%),(10 \%),(10 \%)$ and $(5 \%)$ of respondents has access to computer system, internet service, Online Electronic library, Multimedia projector, Television and Video recorder respectively, this contrasts $(10 \%),(3 \%),(0 \%),(2 \%),(5 \%)$ and $(4 \%)$ respectively obtained by Oviawe \& Oshio (2011) in a similar research.

Research Question 2: Are ICT facilities adequately utilized in enhancing teaching and learning in tertiary institutions in Benin City metropolis?
Table 2. How would you rate the use of ICT facility in teaching and learning at your institution?

\begin{tabular}{|l|l|l|}
\hline $\begin{array}{l}\text { Rating of ICT use in } \\
\text { teaching and learning }\end{array}$ & Frequency & Percentage (\%) \\
\hline Hardly ever & 28 & 14 \\
\hline Regularly & 62 & 31 \\
\hline Very regularly & 110 & 55 \\
\hline Total & 200 & 100 \\
\hline
\end{tabular}

From Table 2, the response to the research question shows that majority of respondent rate the use of ICT facility in teaching and learning to be very regular $(55 \%)$ and regular $(31 \%)$ while $14 \%$ of respondent hardly ever use ICT facility in teaching and learning.

\subsection{Testing of Null Hypothesis}

To test the effect of ICT use in tertiary institutions and enhancement in teaching and learning Table 3, test of independence using chi square. 
Table 3. ICT use in tertiary institutions versus enhancement in teaching and learning

\begin{tabular}{|l|l|l|l|}
\hline Variables & Yes & No & Total \\
\hline ICT use in tertiary institution & 172 & 28 & 200 \\
\hline Enhancement in teaching and learning & 132 & 68 & 200 \\
\hline Total & 304 & 96 & 400 \\
\hline
\end{tabular}

Ho: Enhancement in teaching and learning is independent on ICT use in tertiary institution.

$\mathrm{H1}$ : Enhancement in teaching and learning is NOT independent on ICT use in tertiary institution.

Table 4. Chi-Square Tests

\begin{tabular}{|l|c|c|c|c|c|}
\hline & Value & df & $\begin{array}{c}\text { Asymp. Sig. } \\
\text { (2-sided) }\end{array}$ & $\begin{array}{c}\text { Exact Sig. } \\
\text { (2-sided) }\end{array}$ & $\begin{array}{c}\text { Exact Sig. } \\
\text { (1-sided) }\end{array}$ \\
\hline $\begin{array}{l}\text { Pearson Chi- } \\
\text { Square } \\
\begin{array}{l}\text { Continuity } \\
\text { Correction }\end{array}\end{array}$ & $21.930^{\mathrm{a}}$ & 1 & .000 & & \\
$\begin{array}{l}\text { Likelihood } \\
\text { Ratio } \\
\text { Fisher's Exact } \\
\text { Test } \\
\text { N of Valid } \\
\text { Cases }\end{array}$ & 22.464 & 1 & .000 & & \\
\hline
\end{tabular}

Result indicates a calculated chi square value of 21.930 against table value of 3.841 , also the $P$ value of $<0.0001$ shows a very high significant difference. Since there is a significant difference in chi square calculated value and chi square table value, we reject $\mathrm{Ho}$ and accept $\mathrm{Hi}$, and conclude that enhancement in teaching and learning is dependent on ICT use in tertiary institution. Therefore, to enhance teaching and learning in tertiary institutions, ICT deployment in teaching and learning is necessary. Similar results by Coates et al (2005) and Astin (1999) revealed a significant increase in learning ability of ICT taught students over the non-ICT taught students. This study also agrees with that of Okeh \& Opone (2007) who stated that ICT gives room for effective learning and creates a fast and better method of collecting, processing, compiling and disseminating information to support students and researchers in both inside and outside institutions. (Okeh \& Opone,2007; Coates et al, 2005; Astin, 1999) corroborates the outcome of the results showing that ICTs use in teaching and learning has a significant positive influence in effective dissemination and engagement of students academic activities resulting in increased learning ability.

\section{Conclusion and Recommedation}

The result of this investigation has revealed the importance and dependence on ICT tools in enhancing teaching and learning in tertiary institutions in Benin metropolis. The findings from this study revealed that regardless of the obvious benefits ICT tools brings into teaching and learning, 127 (98\%) of University of Benin respondents agreed that ICTs are used more in administrative purposes such as hostel allocation, course registration etc as compared to teaching and learning while 49 (70\%) respondents supported the same notion in Benson Idahosa University. Though there is significant investment in ICT facilities in both institutions, however ICT tools for teaching and learning are yet to receive the attention it deserves. It is recommended that the institutions should invest more in class room educational tools (ICT) teaching and learning tools hence instructors or lecturers should be trained on the use of these tools, practical ICT education should be integrated into school curriculum and students should be encouraged to use ICT tools in their studies, examinations and submission of assignments.

\section{References}

[1] Adeyemi, T.O. and Olaleye, F.O. (2010). Information communication and Technology (ICT) for the effective management of secondary school for sustainable development in Ekiti state, Nigeria American-Eurasian Journal of Science Research 5 (2): 106-113.

[2] Astin, A.W. (1999). Student involvement: A developmental theory for Higher Education. Journal of College Student Development, 40 : 518-529.

[3] Bransford, J., Brown, A.L and Cocking, R.R (2000): How People Learn: Brain, Mind, Experience and School, (2nd Ed). Washington D.C, National Academy Press.

[4] Coates, H., James, R., \& Baldwin, G. (2005). A critical examination of the effects of learning management systems on university teaching and learning. (journal Article). Tertiary education and management, 11(2005), 19-36.

[5] Federal Republic of Nigeria, National Information Communication Technology (ICT) Policy Draft (January 9, 2012) by The Ministerial Committee on ICT Policy Harmonization. (www.commtech.gov.ng/downloads/National_ICT_Policy_DRAF T_090112.pdf) retrieved on $24^{\text {th }}$ October, 2012.

[6] Iloanusi, O. and Osuagwu, C. (2009): Research, Reflections and Innovations in Integrating ICT in Education, available online at http://www.formatex.org/micte2009/book/1331-1335.pdf.

[7] Moursund,D. G. (2005). Introduction to Information and Communication Technology in Education,,University of Oregon, Eugene, http:// uoregon.edu/\% 7emoursund /Books /ICt/ ICTBook.pdf.

[8] Okeh, O.D. and Opone, M.C. (2007) Information and Communication Technology (ICT): A veritable tool for national Educational Growth, Journal of Academics, 2(3) (2007), 234-246.

[9] Oviawe, J.I. and Oshio, L.E. (2011): Impact of Information and Communication Technology on Teaching and Learning Ability of Education Students in Universities in Edo state, Nigeria. International Review of Social Sciences and Humanities vol.2, No. 1.

[10] University of Benin, (2012). Orientation brochure 2011/2012 session. Benin City; Student Affairs Division. 89p. 